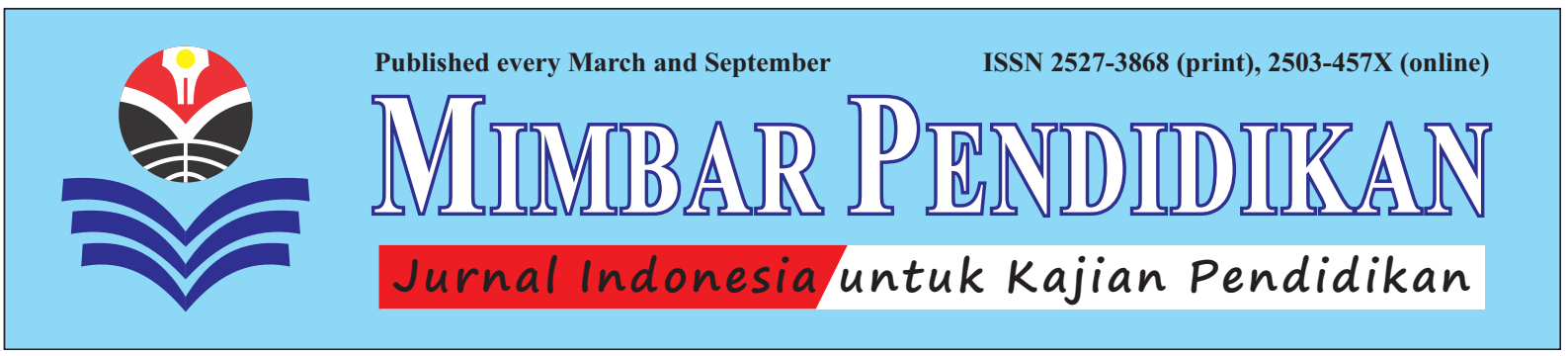

\author{
NNAMDI OGBODOAKUM \& NORHASNI ZAINAL ABIDDIN
}

\title{
Theory of Planned Behaviour and Readiness for Changes: Implication for Organisations
}

\begin{abstract}
An organisation's long term survival in today's challenging environment will depend on constant adaptation to changes in the environment. The majority of behavioural theories acknowledged individual as the central focus. Certain environmental or situational factors and applicable change-related processes have been recognised and studied as having significant influence in determining individual, group, and organisational behaviours. In the context of readiness for change, the theory of planned behaviour would be suitable in assessing the change supporting attributes of employees in achieving a strong readiness for change status. The connection between the theory of planned behaviour and individual readiness for change is that if a person has positive evaluation of change effort (attitude), supported by his close peers (subjective norm), and is confident that such change efforts will be undertaken successfully (perceived behavioural control), there will be improved motivation (intention) to actually engage in the change effort (readiness for change). This paper will discuss the Theory of Planned Behaviour and the readiness for change in organizations.
\end{abstract}

KEY WORD: Readiness for Change; Attitude; Intention; Organisation; Human Resource Development.

ABSTRAKSI: "Teori Tingkah-Laku Terancang dan Kesediaan untuk Berubah: Implikasi pada Organisasi". Jangka hayat sesebuah organisasi dalam persekitaran yang mencabar hari ini bergantung kepada penyesuaian yang berterusan terhadap perubahan persekitaran. Kebanyakan teori tingkah-laku mengakui bahawa individu merupakan tumpuan utama dalam perubahan. Faktor persekitaran atau situasi tertentu dan proses yang berkaitan dengan perubahan juga telah diiktiraf dan dikaji sebagai mempunyai pengaruh yang besar dalam menentukan tingkah-laku individu, kumpulan, dan organisasi. Dalam konteks kesediaan untuk berubah, teori tingkah-laku terancang adalah sesuai dalam menilai perubahan sifat-sifat pekerja dalam menentukan kesediaan mereka yang kukuh untuk berubah. Hubungan antara teori tingkah-laku terancang dan kesediaan untuk berubah adalah berkaitan dengan: seseorang mempunyai penilaian positif terhadap usaha untuk berubah (sikap), disokong pula oleh rakan-rakannya yang rapat (norma subjektif), dan yakin bahawa usaha perubahan tersebut dilaksanakan dengan jayanya (kawalan tingkah-laku) dan motivasi yang ditambah baik (niat) akan benar-benar terlibat dalam usaha perubahan (kesediaan untuk berubah). Artikel ini menerangkan tentang Teori Tingkah-Laku Terancang dan kesediaan organisasi untuk berubah.

KATA KUNCI: Kesediaan untuk Berubah; Sikap; Niat; Organisasi; Pembangunan Modal Insan.

About the Authors: Nnamdi Ogbodoakum is a Ph.D. Student at the Department of Professional Development and Continuing Education, Faculty of Educational Studies UPM (Putra University of Malaysia) in Serdang, Selangor, Malaysia. Assoc. Prof. Dato Dr. Norhasni Zainal Abiddin is a Senior Lecturer at the Department of Professional Development and Continuing Education, Faculty of Educational Studies UPM, 43400 UPM Serdang, Selangor, Malaysia. E-mail: nonie@upm.edu.my

How to cite this article? Ogbodoakum, Nnamdi \& Norhasni Zainal Abiddin. (2017). "Theory of Planned Behaviour and Readiness for Changes: Implication for Organisations" in MIMBAR PENDIDIKAN: Jurnal Indonesia untuk Kajian Pendidikan, Vol.2(1) March, pp.1-18. Bandung, Indonesia: UPI [Indonesia University of Education] Press, ISSN 2527-3868 (print) and 2503-457X (online).

Chronicle of the article: Accepted (November 29, 2016); Revised (January 25, 2017); and Published (March 30, 2017). 


\section{INTRODUCTION}

Organisations are increasingly being challenged in all fronts. From competitive pressures within their respective industries driven by growing customer sophistication and changing demographics to external threats occasioned by globalisation and regulations. Organisation long term survival in today's challenging environment will depend on constant adaptation to changes in the environment (Babatunde \& Adebisi, 2012). The global change dynamics is not the exclusivity of the private sector.

Government agencies are coming under increasing assaults, due to rising wastages, poor services, red tape, and considerably inefficiency in public service delivery together with poor accountability. In other to address, these and other seemingly increasing public resentments; effective change is needed to promote efficiency, productivity, public trust, and confidence in managing public goods and services.

Every year, huge sums of money are allocated on new technologies with the aim of maintaining improved performance. In the many organisations, there have been increasing demand for consultants in training and performance improvement programs, with the sole objective of boasting productivity, increase performance, implement new and complex strategy.

However, such performance improvements programs have failed dramatically to address the problems let alone anticipate sustained competiveness (Mulford, 2003).

Although the role of technologies in promoting organisational efficiency may not be questioned, what is and should not be in doubt is the role of employees in managing and implementing change. While artificial intelligence and other technological sophistications are making serious in-road in our work places, in terms of performance and productivity, the capacity of the human minds that built those machines deserves commendation, support, and motivation for greater human security, dignity, and wellbeing.

In 2007, McKinsey report, as cited by M. Barber, A. Levy \& L. Mendonca (2007), argue that public sector organisation's desire to implement robust change will requires new managerial ability in the same way with policy expertise. The authors supported the idea of expanding the pool of available talent, where the public institutions would recruit and hire suitably qualified individuals (Barber, Levy \& Mendonca, 2007).

Although this position is highly commendable, without effective readiness for change amongst the organisational members, very little positive outcomes would be achieved. Public servants all over the world are the anchor of government service delivery. Their effectiveness or otherwise would ideally promote or hinder the ability of the government to deliver much cherished public goods (Lufunyo, 2013).

Too much focus on conformity and related technicalities by the bureaucrats had sapped the required incentives to implement needed change in government agencies. While, tremendous change programmes have been implemented to optimize organisational performance, substantial number of them had failed to achieve the intended objectives. The high number of failure is not that the desired change is not needed or the mode of implementation not effectively conceived, instead the seemingly sky rocketing change failures is attributed to lack of change readiness within the organisation before such change is conceived and possibly introduced.

How can the intended change deliver the desired objectives, when the organisation and employees are not ready for change? When the organisation and its employees are not ready and willing to change, not only that planned change will not be addressed, instead, emergent change will not be attended to, due to inflexibility in the organisational structure.

Public servants received greater punishment, when mistakes are made 
and little praise when improvements are achieved. This incongruity not only promotes mediocrity and complacency; it stifles creativity and innovation, which are the critical ingredients for sustained performance.

\section{METHODS}

The report is based on examination of literatures on readiness for change. Various approaches and positions on readiness for change would be outlined in other to understand the urgent need to manage change effectively, especially in public sectors and industries, where changes have not achieved the intended objectives (Cohn \& Pannone, 2015).

The core tenet of the article is to synthesis the various positions and viewpoints on readiness for change in the context of theory of planned behaviour, so that a unified position would be adopted on the importance of achieving sound and sustainable performance in the workplace, which will drive improved individual, organisational, and overall national productivity. Interestingly, this is not a comprehensive review on the issues; rather, it is a genuine effort to highlight the relevance of TPB (Theory of Planned Behaviour) in understanding organisational readiness for change (Ajzen, 1991).

\section{RESULTS AND DISCUSSION \\ Concepts and Issues on Readiness}

for Change. Public sector employees are being challenged to improve performance. This is coming on the heel of growing resentment on the part of the citizenry for improved accountability on huge resources being consumed by the nation-state and its agencies. While, the new public management had brought-in private sector based models in the public sector management (Pollitt \& Bouckaert 2011), very little has been achieved in terms of efficiency and effectiveness in service delivery (Halligan, 2010).
The urgency to achieve superior performance in the civil service has been credited with myriads of performance improvement programmes, which have not measured up to the hype (Kim \& Lee, 2009). One notable culprit for the poor and abysmal performance is improper understanding and assessment of environmental differences between private and public sector institutions.

E.B. Dent \& S.G. Goldberg (1999) posit that employee do not necessarily resist change, instead employees normally oppose outcome of change in terms of loss of pay, status, and other comforts (Dent \& Goldberg, 1999). The above misconception in targeting resistance for change (negative mind-set), instead of creating readiness for change (positive disposition) towards organisational improvement, has resulted in poor outcomes of various change intervention programmes.

It is suggested that creating sufficient readiness for change will lead to positive and result oriented change implementation (Oakland \& Taner, 2007). In this context, Kurt Lewin (1947), as reported also in F.H. Rusly, J.L. Corner \& P. Sun (2012), proposed three important change progressions: unfreezing, changing, and refreezing (Lewin, 1947; and Rusly, Corner \& Sun, 2012). Drawing from Kurt Lewin (1947)'s model of change, A.A. Armenakis \& A.G. Bedeian (1999) proposed three stages of stage, which includes: planning for change, acceptance of change, and institutionalization of change (Lewin, 1947; and Armenakis \& Bedeian, 1999). F.H. Rusly, J.L. Corner \& P. Sun (2012) posit again that change effectiveness is achieved, when there is sufficient readiness at the initial stage (Rusly, Corner \& Sun, 2012).

C.C. Dalton \& L.N. Gottlieb (2003) assert that readiness comprises a state and a process. Being a state, readiness is viewed as needed and desirable, including the capacity of the environment to support the change (Dalton \& Gottlieb, 2003). As a process, readiness is concerned on how to implement 
the change together with the potential benefits and costs of the change. Readiness for change is also viewed as the preparedness and capacity to support change (Elias, 2009).

It is also the conviction that change is needed, and the organisation has the necessary competency to implement it successfully (Armenakis \& Harris, 2009; and Rinuastuti et al., 2014). Resistance for change is usually credited with insufficient and in most cases lack of readiness for change before implementing the change programme (Boohene \& Williams, 2013; and Hallinger \& Bryant, 2013).

In this context, J.B. Weiner (2009) states that organisation readiness for change is the shared resolve of members to implement change or commitment; and their collective ability to implement the change successfully or efficacy (Weiner, 2009). If the readiness for change is strong, as argued by $\mathrm{J}$. Wallinger (2008), positive change outcome will be achieved (Wallinger, 2008).

Levels of Change. Readiness for change is both multi-level and multi-dimensional. On the level perspective, we have individual, group, and organisational levels of change. Readiness can be conceptualised in either of the following point: individual, group, unit, and organisation (Weiner, 2009). The level of analysis adopted, as indicated in the above classification, is particularly important in managing change related works. Although, readiness has been described as the willingness and ability to implement change, which is consistent with A. Bandura (1997)'s goal commitment, organisational level basically involves organisation members shared resolve to undertake and implement change (cf Bandura, 1997; and Weiner, 2009:2).

L. Herscovitch \& J.P. Meyer (2002) outlined three different perspectives, where organisational members would respond to change: (1) Members want change, under this domain, organisational members value the change; (2) Members have to change, here the employees have little choice for otherwise; and (3) Members are obliged to change, the authors conclude that commitment to change is best achieved at the first domain, because required "buy in" is mostly developed since the employees value the change, and in most cases are willing and able to support the change (Herscovitch \& Meyer, 2002).

\section{First, Individual Level of Change.} Individual readiness for change is the state of readiness, which an individual member of organisation possesses. Although change would be assessed at either individual, group, and organisational level, individual level of assessment could be the anchor of all other levels of assessment, due to the central role of individual in championing group or organisational objectives.

D. Katz \& R.L. Kahn (1978) suggest that the unique role of individual in any change intervention effectively makes organisational change heavily dependent on individual disposition (Katz \& Kahn, 1978). Individual interactions with the environment determines individual disposition towards change and other work related attitude and behaviours. Psychology and sociology have impacted significantly on the individual behavioural models (Loewenstein et al., 2011).

Consistent with the idea of unfreezing by Kurt Lewin (1947), individual readiness for change is an important factor in implementing change. When organisational leaders understand the conditions, which support high readiness for change amongst the employees, improved performance is achieved (Lewin, 1947). This stance is particularly useful, because it positions the organisation on the part of positive attitudinal disposition, instead of the usual focus on the negative perception on how to stop seemingly non-existing resistance.

Even though sociology and psychology models are in agreement with rational economic paradigms, which explain individual economic behaviours in a 
particular context, social-psychological stance which focuses on human behaviours represents a wider perspective (Shah \& Dawnay, 2005). In this manner, G. Loewenstein et al. (2011) also argue that social-psychological paradigms expand the linear model of economic theory in the context of other factors, which would predict individual behavioural disposition (Loewenstein et al., 2011).

It is our considered opinion that individual level of change is the foundation of other levels of change, where readiness for change would be assessed and theorised. Instructively, if the individual employees or staff members are not willing and able to support change, other unit of analysis involving change would be hindered. If workers are not prepared to embrace change, desired organisational objectives may not be achieved. Also, if employees are supported with right organisational climate, such as trust, effective leadership, and motivation, the likelihood of strong employee "buy in" is encouraged with resultant high degree of readiness to support change.

Second, Group Level of Change. Group readiness for change is another level of change, which is necessary in building effective team work and organisational effectiveness. Again, Kurt Lewin (1947)'s model of change progression is an important contribution in the theory of dynamics. Kurt Lewin's model address two fundamental questions: (1) what forces are in a group, which influences their particular behaviours; and (2) how would these forces be changed in other to have an acceptable behaviour ( $c f$ Lewin, 1947; and Burnes, 2004).

According to Kurt Lewin's model, the degree of interaction which the group have with the environment represents the fields or group forces. Proper and effective understanding of the group forces will be important in changing the group behaviour for better. Kurt Lewin's position was that in other to ensure effective change management, it must begin with real motivation for change (unfreezing). Under this phase, organisational members are encouraged to challenge their beliefs, attitudes, and orientation towards the change (Lewin, 1947).

Essentially, this phase is where the readiness for change is created in the organisation. After the unfreezing stage, the change begins with adoption of new work process, systems, and technology for the desired change. Once the initial uncertainties created from the unfreezing stage appear to settles, employees start to apply the new attitudes and behaviours expected in the work. It is instructive to state that under this stage not everyone will be on board; hence, there is needed to reassure employees that the change is a worthwhile exercise which will benefit everyone. The final stage is the institutionalisation, where the employees internalize the change effort for stability. This stage is, particularly, useful in building the needed flexibility amongst the members, which is vital in future change programme in the organisation.

Although, Kurt Lewin's model has been criticised for being too simplistic, static, and lacking in empirical confirmation, it is widely credited for providing profound insights into the change dynamism, which if effectively contextualised will help to understand and internalise organisation change and change improvement strategies (Lewin, 1947; and Burnes, 2004).

In the public sector setting, where there is marked hierarchical structure, inhibiting cultural setting together with rules and procedure, what influences group behaviours, and how group behaviours would be modelled to achieve organisational objectives will be paramount. Public servants just like other employees group is a close knitted group, where group interactions have significant influence on individual, group, and eventual behaviours. Accordingly, in a unionised environment where public sector employees operate, group norm and 
roles will continue to shape the behavioural outcomes.

Instructively, readiness for change in a public sector organisation, such as the civil service, requires accurate and effective assessment of the group norms and roles, so that staff members will be ready to support the change. Following the adoption of New Public Management principles into the public sector, it is viewed that the new insights would support and enthrone acceptable group behavioural pattern.

H.G. Frederickson et al. (2012) argue that in group setting, shared goals, values, and norms are developed which in the context of effective management and organisational leadership will promote organisational compliant behaviours and positive attitudinal disposition towards goal attainment (Frederickson et al., 2012).

Third, Organisational Level of Change. Whereas numerous organisation change interventions have failed to deliver the desired goals, very few questions have been directed to the reason(s) behind the huge failures. From industry to industry, the outcome is the same. Organisation change had failed to achieve the intended results (Weiner, 2009; Wekman, 2009; Self \& Schraeder, 2009; and Grady \& Grady, 2013).

In the viewpoint of A.A. Armenakis \& S.G. Harris (2009), it is meaningless to undertake a change if the employees are not willing and able to support the change (Armenakis \& Harris, 2009). The magnitude and pace of change has increased dramatically (Grady \& Grady, 2013). Even though such changes are aimed at improving organisational performance, very few have achieved the desired outcome (Self \& Schraeder, 2009; and Cawsey, Deszca \& Ingols, 2012).

Numerous theories have been advanced to explain the content and process of change. Some scholars argue that change is planned goal directed (Van de Ven \& Poole, 1995; and Paton \& McCalman, 2008); dialectical theory suggest that change may happen when distinct forces combine to challenge the existing order (Van de Ven \& Poole, 1995; and Wekman, 2009); and continuous and on-going process (Cawsey, Deszca \& Ingols, 2012).

Although it has been noted that employee resist change, E.B. Dent \& S.G. Goldberg (1999) stated that employees would not necessarily resist change; rather, they resist change outcomes, such as income, status, position, and influence which current position allows (Dent \& Goldberg, 1999). It is suggested that organisational leaders create appropriate "buy in" amongst the employees before, during, and after the change (Wallinger, 2008; and Self \& Schraeder, 2009).

Organisation level is the third level, which readiness for change can be assessed. In this context, J.B. Weiner (2009) states that organisation readiness is the willingness of the members in an organisation to implement change (change commitment) and their shared ability to implement the said change successfully (change efficacy). It is established that improper assessment of readiness status of organisations may be attributed to the increasing failures of various intervention programs ( $c f$ Weiner, 2009; and Grady \& Grady, 2013).

Ascertaining the level readiness prior to change implementation is credited with strong organisational support and resultant goal attainment (Jones, Jimmieson \& Griffiths, 2005). Again, J.B. Weiner (2009) asserts to the multi-faceted nature of organisational readiness in terms of processes, procedures, and polices, including task demands, situational factors, and resources availability, requires a holistic approach in managing organisation interventions (Weiner, 2009:2).

An organisation with high state of readiness is usually characterised with open communication, trust, effective leadership, and supporting organisation culture (Armenakis, Harris \& Mossholder, 1993; 
Armenakis et al., 2007; and Weiner, 2009). The core argument is that when the above contextual factors are properly factored into the organisational fabrics before and during change readiness assessment, improved and strong readiness is achieved.

J.D. Ford \& L.W. Ford (2009) state that resistance being an organisational manifestation of individual and group behaviours would be drastically reduced if high state of organisational readiness for change is attained (Ford \& Ford, 2009). A.A. Armenakis, S.G. Harris \& K. Mossholder (1993) also maintain that the relationship between individual and group readiness for change could either improves organisational readiness with supporting behavioural disposition of members or hinder organisational readiness with marked resentments and resistance towards desired organisation objectives (Armenakis, Harris \& Mossholder, 1993).

Substantial resources have been expended to stop resistance, which may not necessarily be the case, as suggested by E.B. Dent \& S.G. Goldberg (1999), instead of investing scarce resources to seek and promote employee readiness for change, which is much more positive oriented (Dent \& Goldberg, 1999). It is noted, in some instances, that where organisational managers and leaders fail to create sufficient readiness prior to change commencement, such change implementation has failed to deliver the expected outcomes, due to heightened resistance, fear, and anxiety.

In some cases, employees were known to offer limited support in form of "wait and see", especially in government agencies and departments. It is our opinion that readiness for change should not only be created prior to change commencement, instead it should be enthusiastically and energetically promoted throughout the organisation; otherwise change may be viewed as task specific instead of promoting an organisation agility to respond effectively and proactively to change.
Fourth, Self-Efficacy and Readiness for Change. Following the publication of the seminar work by Albert Bandura (2006) on self-efficacy, several authors have applied the theoretical underpinnings to evaluate individual ability to successfully engage in an activity (Bandura, 2006). Although the theory was initially focused on psychology, it has been successfully proved efficacious in other fields, such as medicine, healthcare, substance use, psychopathology, political change, social order, business, government, and international affairs (Pajeres, 1996; and Bandura, 2006).

According to Albert Bandura (1982 and 1997), self-efficacy is central to human activity. Even though individual possession of needed skills and knowledge of a given activity is very important, such individual should be convinced that he/she would successfully execute such task (Bandura, 1982 and 1997). The implication is that possession of skills and/or knowledgeable of the act alone, may not be sufficient to undertake a given task successfully. Albert Bandura argues that self-efficacy influences three key individual pattern of behaviour: (1) choice of activities; (2) effort in the activity; and (3) persistence in a challenging activity (Bandura, 1982 and 1997).

According to the authors, individual with low self-efficacy towards a given task could avoid it, while those with high self-efficacy would be more disposed to engage in such a task. Similarly, it was hypothesized that individuals with strong efficacious belief are more likely to apply additional efforts, including longer persistency during tough and challenging task. Many organisational change programs have failed to achieve the intended outcome, because employees are not ready to cope with such challenging task, or the said task was not properly designed and implemented. Knowledge of self-efficacy is vital in any intervention.

Individual belief on his/her ability to successfully undertake a given task does not 
happen by chance, instead it is developed from four major sources: (1) enactive mastery experiences; (2) observation of others; (3) verbal and non-verbal persuasion; and (4) individual affective or physiological state (Bandura, 1997). Enactive mastery experience is recognised as the most effective source of self-efficacy, because it provides compelling and authentic evidence, where an individual would obtain individualised resources for success. It is also argued that previous successes increase individual selfefficacy, while repeated failures reduce selfefficacy. It follows that when individual selfefficacy is improved, repeated successes are witnessed; and, thus, there would be a reduced impact of occasional negative experience (Pajeres, 1996; and Bandura, 2006).

In general, individual overall self-efficacy is dependent on the strength of the current belief and the timing of the failures. By implication initial failures would exert significant negative impact on self-efficacy than recent failures (Bandura, 1997). In the context of readiness for change, past experiences play an important role in promoting individual readiness for change; thus, an individual with positive past evaluative experience concerning a task would be more open to support change, while less support to change may be witnessed, if such experience is negative. For example, in an organisation where previous change interventions have failed, it would be foolhardy to assume that current or future change would succeed without creating sufficient readiness for change.

Such readiness could be created through a compelling position on the need for change together with expected positive impact in achieving individual and organisation objectives. Furthermore, even when employee understood the urgency of the change in achieving positive organisation performance, employees may be reluctant to support the change if proper and effective public advocacy within the organisation is not promoted.
The second efficacy source is the observation of others. Whereas enactive mastery experience is adjudged to be most potent source of efficacy belief, an individual self-efficacy is said to improve by observing other peoples successes and failures (Bandura, 1997). The central point from this source of self-efficacy is that when an individual observes another person engaging in a task, the person's efforts and persistence in similar future situation could increase. This form of efficacy is consistent with perceived behavioural control in theory of planned behaviour (Conner \& Armitage, 1998).

In fact, perceived behavioural control is believed to have been borrowed from this component of self-efficacy theory. Instructively, when an individual sees other peoples performing a task, his/her disposition towards the task or similar task could either increase or decrease depending on the strength of information received. In organisation setting, it is noted that strong and positive readiness for change are created when employees interact closely and effectively with peers, friends, and associates. Through this means, individual encouragement is promoted with resultant positive change readiness.

Individual self-efficacy may also come from persuasion, either verbal or non-verbal. This form of efficacy is widely credited with academic improvement, where students are encouraged to participate in sometimes challenging academic exercise. About the verbal persuasion, Albert Bandura (1997) stated as follows:

$[\ldots]$ verbal persuasion alone may be limited in its power to create enduring increases in perceived efficacy, but it can bolster selfchange if the positive appraisal is within realistic bounds (Bandura, 1997:101).

Accordingly, according to Albert Bandura (1997), overbearing persuasion on individual may be counterproductive if on the process 
of persuasion, the individual encounter failure, which could demotivate current and even future efforts (Bandura, 1997). For change to be effective, motivational ingredient of change should drive the change efforts. Essentially, individual personal disposition regarding the change influences one's self efficacy.

In organisation setting, although persuasion in some instances is believed to be effective in promoting successful performance of a given task, the result of such may not provide the needed results in government agencies and parastatals, where entrenched and special interest generally prevent genuine collaboration, mentorship, and potential innovation, which are critical in promoting effective and efficient organisational improvement.

The fourth efficacy source is information assessment. How individual assess and interprets information generally influences his/her reaction to change efforts. For example, in many physical challenging activities with significant stress, fear, and anxiety, it is believed that excessive emotional and physiological arousal could affect one's personal disposition negatively (Bandura, 1997). When an individual fear and anxiety level is extended beyond one's limit, additional impediment is developed which could hamper efficacy status.

Accordingly, if the efficacy status is lowered as indicated above, the propensity of the individual to engage in any similar activity successfully is reduced. In change readiness efforts, how an employee process and interpret information is considered vital in managing change.

In any establishment, information assessment and feedback during performance of any task is particularly useful in evaluating one's efficacy status and eventual behavioural disposition. It is very evident that information assessment and feedback generated from previous work role could affect individual self-efficacy and behavioural disposition. Effective change readiness in this context will depends on promoting positive collaboration, feedback, and encouragement through open and directed communication to dispel fear and anxiety. An essential feature of self-efficacy is that it is context dependent.

Albert Bandura (2006) again posits that individuals make an evaluative judgment of their ability in reference to the context of the task (Bandura, 2006). Accordingly, individual self-efficacy is not one size fits all scenarios instead it is domain specific. Success in a given task is not a guarantee for success in another task, even though the two tasks may by similar. In other to obtain a strong positive predictive power of self-efficacy, it is should be properly contextualised and appropriate measures clearly defined to capture the issue being measured (Bandura, 2006).

\section{Theories and Model of Behavioural}

Change. Human behaviours have been greatly influenced by the social sciences. Theories and models are designed to explain the conditions which support a particular course of action. Why an individual behaves and circumstances which could influence future behaviour in similar conditions have dominated researches. Unquestionably, disciplinary boundaries are set between behaviours under various conditions and tools; and methodology which would be adopted in studying or measuring such behaviours. Accordingly, it would be impossible to offer comprehensive reviews of all the behavioural theories and models. Many behavioural theories and models regards individual as the locus or the source of the behaviours (Conner \& Armitage, 1998; and Bandura, 2006). This may be connected with the significant influence, which psychology had in defining and modelling human behaviour.

Whereas majority of behavioural theories and models conceptualised individual as the central focus, certain environmental or situational factors and applicable change 
related processes have been recognised as having significant influence in determining individual, group, and organisational behaviours. In some perspectives, other behavioural theories focus on interplay between behaviours, environment, and other supporting structures (Shove, 2010; and Prager, 2012).

Social system theories and diffusion of innovation tends to assume that behaviours itself is the product of interrelationships and social practices in the environment (Shove, 2010; and Prager, 2012). Whatever the classification may be, the common denominator in behavioural theories and models is that individual psychological factors together with contextual issues are important in predicting individual disposition towards change (Fishbein \& Ajzen, 1975). It is also instructive to note that since change is both content and context dependent, understanding how and why people respond to change interventions will be important in building a result oriented workforce.

First, Theory of Planned of Behaviour. Theory of reasoned action and theory of planned behaviour suggest that behaviour to engage in an activity is dependent on intention. Intention, accordingly, is determined by individual attitude and subjective norms (theory of reasoned action) and perceived behavioural control for theory of planned behaviour. M. Fishbein \& I. Ajzen (1975) argue in the theory of reasoned action that intention is the proximal determinant of behaviour, which in turn is determined by individual attitude towards the change, which is either positive or negative assessment of the attitude object (Fishbein \& Ajzen, 1975). Subjective norm is the thoughts and views of other significant others in ones desire to engage in the act.

The central thesis of theory of reasoned action is that when an individual has positive attitudinal disposition combined with support from other significant people around him/ her, it is argued that intention to engage in a particular activity will be high. Instructively, intention being the proximal factor for behaviours means that proper understanding, assessment of altitude, and subjective norm are essential if the required behavioural intention is to be achieved. Theory of planned behaviour, which is the continuation of theory of reasoned action, also assumes that intention is the proximal determinant for behaviour (Fishbein \& Ajzen, 1975).

Like TRA (Theory of Reasoned Action), TPB (Theory of Planned Behaviour) contains attitude, subjective norms, and perceived behavioural control. The only difference is the inclusion of perceived behaviours control (Ajzen, 1991). Perceived behavioural control is the ease, which an individual beliefs that he/ she can successfully undertake and complete a given task. Based on the shortcoming of the TRA, PBC (Perceived Behaviours Control) in TPB is expected to address the issue of volitional control (Ajzen, 1991).

Perceived behavioural control was based on self-efficacy of Albert Bandura (1982), which was derived from Social Cognitive Theory. As argued by Albert Bandura, individual motivation, expectation, performance, and sense of failures are said to determine the behavioural reactions (Bandura, 1982). Unlike the Theory of Reasoned Action, the core thesis of TPB is that attitude towards change, subjective norms, and ones perceived ability to undertake a task successfully will have a higher explanatory power in predicting intention and subsequent behaviour (Bandura, 1982; and Ajzen, 1991).

Furthermore, for perceived behavioural control to effect behaviours, in the same manner with the notion of self-efficacy, an individual should have the ability to engage in the action (Grizzell, 2007). The TPB has been applied successfully in various fields with strong empirical results. M.H. Hsu et al. (2006) applied the theory to examine the online shopping behaviour. It was found that there are statistically significant relationships 
among the model antecedents with behaviour (Hsu et al., 2006).

R.P. Robinson \& D. Doverspike (2006) found that university teachers' preference for a particular teaching method is based on perceived behavioural control (Robinson \& Doverspike, 2006). This finding is particularly useful in understanding how government employees respond to change, especially adoption of modern tools in the workplace. M.C. Lee (2009) found that students' adoption of online podcast was successfully predicted by TPB (Lee, 2009). The efficacy of TPB in predicting individual behaviour towards an act has not been questioned. What is still subject to various interpretations and intense debate is the amount of variance explained by the model antecedents. C.J. Armitage \& M. Conner (2001) reviewed 185 studies where TPB has been used, it was discovered that about 20$30 \%$ was of variances were predicted by TPB (Armitage \& Conner, 2001).

W.I.W. Ahmad, Z. Ismail \& A.H.A. Rahman (2011) used the theory to examine the intention of elderly people to engage in an exercise in Malaysia. Out of 65 respondents which was divided into two groups: exercise group has 34 peoples made up of 25 males and 9 females; the control group has 31 respondents comprising 22 males and 9 females. It was found that attitude and perceived behavioural control are the greatest predictors of intention to engage in an exercise. Furthermore, among female respondents, subjective norm has the greatest influence on intention to engage on exercise (Ahmad, Ismail \& Rahman, 2011).

M.T. Al-Ziadat (2015) used TPB to predict international tourists revisit intention and actual visit behaviour in Jordan. With a sample of 403 respondents, it was discovered that attitude and subjective norms predicted intention to revisit, while revisit intention and PBC have strong and positive effect on actual visit behaviour (Al-Ziadat, 2015). As indicated in both TRA and TPB, intention as the proximal determinant of behaviour is suggestive that one's motivation is customarily associated with behaviour.

The implication is that in other to ensure a robust and effective readiness for change towards organisation intervention, it is recommended that positive supporting messages and information towards the intervention should be promoted before and during the change. The above position is extremely important in predicting the likely behaviour, which will be targeted for change, before change is introduced. One plausible path is the creation of readiness through change supporting behaviours. In government agencies and departments, where rules and procedures together with inhibiting culture, understanding staff intention will be important in targeting positive attitudinal disposition towards change effort.

Although the explanatory sufficiency of subjective norm has been questioned in the TPB, it has been suggested by C.J. Armitage \& M. Conner (2001) that apparent weakness in subjective norm may be methodological, due to strong relationship which the construct has shown in some studies (Armitage \& Conner, 2001). Also, attitude and perceived behavioural control which have consistently showed similar pattern with intention may equally exhibit better than expected results in other situations. Some scholars have argued that TPB may not be suitable in designing behavioural change intervention (Taylor et al., 2006; and Webb, Sniehotta \& Michie, 2010).

W. Hardeman et al. (2002) assert that TPB is mostly suitable in discovering behavioural determinants, which may be a target for change intervention (Hardeman et al., 2002). While, the theoretical sufficiency of TPB is not in doubt, the divide on how best to apply the theory in current and future behavioural research will continue to surface. In healthcare area, it has been applied successfully in understanding important behavioural intentions towards health related issues, such as smoking cessation, HIV 
(Human Immunodeficiency Virus) prevention practices, and other behavioural changes.

In other sectors, such as shopping habits, technological usage, and performance improvement methods, the theory has proved overwhelming successful in targeting relevant behavioural attributes for change. The core thesis of this article is not to undertake a review of studies, where the theory has been used. Few of the above cited studies should not be used out of context in ascertaining the theoretical balance or otherwise of the model antecedents.

Instead it should be cautiously interpreted in the context of futuristic research domain, which will stimulate learning, support understanding, promote research efforts, and, above all, challenge scholarly debate on individual intention towards behaviour. The seemingly disagreement on explanatory power of subjective norm in the model, even though it may be methodological as argued by C.J. Armitage \& M. Conner (2001) requires a robust and articulated position for improvement (Armitage \& Conner, 2001).

It is advised that subjecting the construct into rigorous testing in other fields, cultures, and situations could offer additional perspectives on intention-behavioural research instead of the usual stand-alone interpretations, which have produced profound distortions and in most cases ambiguity and lack of direction. Even though contextual issues have been studied extensively with respect to individual behaviours, the seemingly disagreement among researchers on the behaviours of some constructs is not because of the constructs itself, instead in many instances, it depend on how those constructs were conceptualised and measured.

Furthermore, it is our opinion that in certain situation, discrepancies exist when researchers want to create a "super model", which would predict behaviours in all conditions irrespective of contextual factors or specific change requirements and/ or dimensions, which influence behaviours under such conditions.

Second, Situational Factors Influencing Readiness for Change. Change does not happen in a vacuum. Successful change implementation does not depend on the content of the change alone, it must be implemented on supportive environment. Individuals exhibit different behaviours under different conditions. The knowledge and proper assessment of situational factors, which could affect change, are essential requirements in designing effective change interventions.

Specifically, J.B. Weiner (2009) outlined some of the situational factors, which according to him are critical to achieving proper organisational readiness for change (Weiner, 2009). Factors such as organisation culture, peer and superior influence, motivation, task demand, and past experience are believed to have significant influence in developing mutual sense of readiness, which is important in achieving high organisation readiness for change.

Culture is the manifestation of values, norms, beliefs, and assumptions which shape people's behaviours (Schein, 1990; and Rodsutti \& Swierczek, 2002). Culture essentially determines the behaviour of members in an organisation as it affect communication; attention to issues in the organisation; and how polices, task, and functions are carried out. J. Melitski, D. Gavin \& J. Gavin (2010) state that culture is the black box of which an organisation will be recognised, assessed, and evaluated on (Melitski, Gavin \& Gavin, 2010).

How an organisation responds to change and other applicable interventions is determined by the culture of the organisation. Some organisation cultural attributes supports innovation and open discussion. Such cultural features, which are generally found in private sector organisations, support high receptivity which is important in achieving positive change behaviours (Dopson et 
al., 2002). It is should be noted that even though high receptivity promotes innovation, learning and readiness for change, in some cases the reverse may be noted, due to strong group norm (Newton et al., 2003). Instructively, an organisation culture where risk taking, learning, and creative thinking are encouraged, organisation readiness for change is strengthened.

Peer and superior influence are other important organisational factors, which influence readiness for change. Trust in one's peers and superiors (managers) are known to have positive and strong effect in creating readiness for change (Madsen, 2003). Another important benefit of peer and superior influence is that such engagement promotes self-efficacy and commitment, which are considered vital in creating readiness of change. For example, when an individual considers the opinion of his/her peers as valuable, the likelihood of the person exhibiting high positive change supporting behaviours may be observed. Similar effect will be noted through the influence of one's superiors.

Consistent with the TPB (Theory of Planned Behaviour), subjective norm may be decomposed into peer and superior influence for more explanatory power, which could have an enhanced effect on intention and corresponding positive behaviour. Albert Bandura (1982) noted that if an individual has low confidence level, his/her capability to engage in an activity successfully will be hampered (Bandura, 1982). The inability to execute such task is due to insufficient or lack of employee motivation, which is an important component for positive change supporting behaviours.

Level of personal confidence and resultant effect on collective-efficacy judgment is particularly useful not only on individual or peer influence regarding change related behaviours; instead organisational readiness to respond to current or future intervention may be derailed. Organizational polices and resource availability could also affect employee response to change related behaviours.

Broadly speaking, organisation polices could either be a positive or negative phenomena on organisation readiness depending on whether it promote employee shared vision for positive change. Or, it may create an atmosphere where fear and suspicion holds sway, which could negatively affect employee performance. In public sector, such practices are usually known to be responsible for nepotism and low productivity. Irrespective of the level of analysis, on which readiness for change could be studied, without shared resolve among the employees, change readiness would be difficult to achieve (Weiner, 2009).

Commitment of members towards the change is always high, when members value the change and are convinced that the organisation has the resources and capabilities to execute the change successfully. It is also important to make a distinction between resources availabilities and other structural organisational effect concerning readiness. For example, two or more organisations with similar resource availabilities and routines may differ on how change is implemented in their respective offices, due to how those resources are deployed. Also, employees could cognitively assess if the organisation is well equipped in terms of finance, personnel, and other critical resources which are vital in implementing the change. Accordingly, members shared resolve to engage in any change related efforts is a multi-dimensional stance, which requires collective knowledge, understanding, judgment, and determined organisational efforts to promote change supporting behaviours (Weiner, 2009; and Shove, 2010).

\section{CONCLUSION}

Numerous organisation change improvements have not delivered the 
target objectives or achieved the intended results, even though significant resources have been allocated. In private sector organisations, such failures have resulted in high management turnover; while in public sector, reorganisations and redeployments of civil servants are on the increase. In the above instances, the common denominator is that for companies, shareholders are responding to competitive pressures occasioned by poor performance to effect the change; while in government agencies and departments, citizenry are demanding proper accountability in service delivery. Although, the private and public organisations have different priorities, policies, and procedures, including different cultural environment, they want competent employees who can deliver improved organisation objectives.

While having competent employees is important in achieving desired organisation goals, very little will be achieved if employees are not ready and willing to do the work. The concept of readiness for change is designed to promote organisation wider support in implementing change related efforts. However, just like other performance improvement programs which have failed to deliver the targeted results because of wrong organisation diagnosis, in most surprising instances, resistance to change has been targeted, which in the opinion of this writers is not only negative and counterproductive, instead it does not present a compelling scenario, upon which a change ready mindset and capability is needed.

Employees do not resist per se, instead they resist change outcomes which are considered hostile to their values, status, interests, and other cherished dispositions. When employees are made to understand the necessity of the change and its benefits "strong buy in" is encouraged with concomitant positive organisation outcomes. Different behavioural models have been devised to explain why individual behaves in a particular way. It has been established that intention is the most proximal antecedent to behaviour. Specifically, the TPB (Theory of Planned Behaviour), which is an extension of the TRA (Theory of Reasoned Action) proposes that when an individual has positive attitude towards an act is supported and encouraged by close peers and superiors, and is confident in his/her ability in undertaking the act, intention towards the act will be high with corresponding positive behavioural disposition in performing the act.

In the context of readiness for change, the central thesis of this review is that antecedents of the TPB would be suitable in assessing the change supporting attributes of employees in achieving a strong readiness for change status. The connection between the TPB and individual readiness for change is that if a person has positive evaluation of change effort (attitude), supported by his close peers (subjective norm), and confident that such change efforts will be undertaken successfully (perceived behavioural control), there will be improved motivation (intention) to actually engage in the change effort (readiness for change).

Although the central focus of the TPB is on individual, without sufficient and effective individual readiness for change, desired organisational outcomes would be elusive. Essentially, an organisational readiness for change comes from strong employees' support and willingness, which may literally translate to robust organisational readiness and possibly improved organisational outcomes.

Our position is that effective application and measurement of TPB would be able to help researchers and practitioners understand and predict individual readiness for change, which if properly harmonised in the content and context of change would provide robust and sustained organisational outcomes. The authors are also suggesting that organisational change is not a one off issues, rather it should be effectively built in the organisational structures, systems, and 
employees alike. An organisation should be agile in other to respond to dynamic environment. ${ }^{1}$

\section{References}

Ahmad, W.I.W., Z. Ismail \& A.H.A. Rahman. (2011). "Aging and Economic Participation of Older Population in Rural Malaysia" in International Journal of Humanities and Social Science, 9(1), pp.128-133.

Ajzen, I. (1991). "The Theory of Planned Behavior" in Organizational Behaviour and Human Decision Processes, 50, pp.179-211.

Al-Ziadat, M.T. (2015). “Applications of Planned Behavior Theory (TPB) in Jordanian Tourism" in International Journal of Marketing Studies, 7(3), pp.95-106.

Armenakis, A.A., S.G. Harris \& K. Mossholder. (1993). "Creating Readiness for Organizational Change" in Human Relations, 46(3), pp.681-703.

Armenakis, A.A. \& A.G. Bedeian. (1999). "Organizational Change: A Review of Theory and Research in the 1990s" in Journal of Management, 25(3), pp.293-315.

Armenakis, A.A. et al. (2007). "Organisational Change Receipients Beliefs Scale: Development of an Assessment Instrument" in Journal of Applied Behavioral Science, 43(4), pp.481-505.

Armenakis, A.A. \& S.G. Harris. (2009). "Reflections: Our Journey in Organizational Change Research and Practice" in Journal of Change Management, 9(2), pp.127-142.

Armitage, C.J. \& M. Conner. (2001). "Efficacy of the Theory of Planned Behaviour: A Meta-Analytic Review" in British Journal of Social Psychology, 40, pp.471-499.

Babatunde, Bayode O. \& Adebola O. Adebisi. (2012). "Strategic Environmental Scanning and Organization Performance in a Competitive Business Environment" in Economic Insights: Trends and Challenges, Vol.LXIV, No.1. Available online also at: http://www.upg-bulletin-se.ro/ archive/2012-1/3.\%20Babatunde Adebisi.pdf [accessed in Serdang, Malaysia: 22 October 2016].

Bandura, Albert. (1982). "Self-Efficacy Mechanism in Human Agency" in American Psychologist, 37, pp.122-147.

\footnotetext{
${ }^{1}$ Statement: We declare that the paper is our original work. It is not a product of plagiarism, and not also be submitted and published by other scholarly journal. If the paper has been received, we will not withdrawal this paper from the MIMBAR PENDIDIKAN journal. We certify that all our statements are true and correct.
}

Bandura, Albert. (1997). Self-Efficacy: The Exercise of Control. New York: Free Man.

Bandura, Albert. (2006). "Guide for Constructing SelfEfficacy Scales" in F. Pajares \& T. Urdan [eds]. Adolescence and Education: Self-Efficacy Beliefs of Adolescents. Greenwich: Information Age Publishing, pp.139-159.

Barber, M., A. Levy \& L. Mendonca. (2007). Global Trending Affecting the Public Sector. London: McKinsey.

Boohene, R. \& A.A. Williams. (2013). "Resistance to Organisational Change: A Case Study of Oti Yeboah Complex" in International Business and Management, (4)1, pp.135-145.

Burnes, B. (2004). "Kurt Lewin and the Planned Approach to Change: A Re-Appraisal" in Journal of Management Studies, 41, pp.977-1002.

Cawsey, T.F., G. Deszca \& C. Ingols. (2012). Organizational Change: An Action-Oriented Toolkit. Thousand Oaks: Sage Publications Ltd.

Cohn, Wendy \& Aaron Pannone. (2015). "Literature Review \& Analysis" in TEACH: Tailored Educational Approaches for Consumer Health. Available online also at: https://med.virginia.edu/ phs/wp-content/uploads/sites [accessed in Serdang, Malaysia: 22 October 2016].

Conner, Mark \& Christopher J. Armitage. (1998). "Extending the Theory of Planned Behavior: A Review and Avenues for Further Research" in Journal of Applied Social Psychology, 28(15), pp.1429-1464. Available online also at: $\underline{\mathrm{http}: / /}$ citeseerx.ist.psu.edu/viewdoc/download?doi [accessed in Serdang, Malaysia: 22 October 2016].

Dalton, C.C. \& L.N. Gottlieb. (2003). "The Concept of Readiness to Change" in Journal of Advanced Nursing, 42(2), pp.108-117.

Dent, E.B. \& S.G. Goldberg. (1999). "Challenging Resistance to Change" in The Journal of Applied Behavioral Science, 35(1), pp.25-41.

Dopson, S. et al. (2002). "No Margic Target!" in Health Care Management Review, 27, pp.35-47.

Elias, S.M. (2009). "Employee Commitment in Times of Change: Assessing the Importance of Attitudes towards Organizational Change" in Journal of Management, 35(1), pp.37-55.

Ford, J.D. \& L.W. Ford. (2009). "Resistance to Change: A Re-Examination and Extension" in R. Woodman, W. Pasmore \& A.B. Shani [eds]. Research in Organizational Change and Development. Bingley: Emerald, pp.211-239.

Frederickson, H.G. et al. (2012). The Public Administration: Primer Theory. Boulder: Westview Press.

Fishbein, M. \& I. Ajzen. (1975). Belief, Attitude, Intention, and Behavior: An Introduction to Theory and Research. Reading, MA: Addison-Wesley. 
Grady, V.M. \& J.D. Grady. (2013). “The Relationship of Bowlby's Attachment Theory to the Persistent Failure of Organizational Change Initiatives" in Journal of Change Management, 13(2), pp.206-222.

Grizzell, J. (2007). "Behavior Change Theories and Models". Available online at: http://www. csupomona.edu/ jvgrizzell/best practices/ bctheory.html [accessed in Serdang, Malaysia: 22 October 2016].

Halligan, J. (2010). "The Reassertion of the Centre in a First Generation NPM System" in T. Christensen \& P. Lægreid [eds]. Autonomy and Regulation: Coping with Agencies in the Modern State. London: Edward Elgar, pp.162-180.

Hallinger, P. \& D.A. Bryant. (2013). “Accelerating Knowledge Production on Educational Leadership and Management in East Asia: A Strategic Analysis" in School Leadership \& Management, 33(3), pp.202-223.

Hardeman, W. et al. (2002). "Application of the Theory of Planned Behaviour in Behaviour Change Interventions: A Systematic Review" in Psychology \& Health, 17, pp.123-158.

Herscovitch, L. \& J.P. Meyer. (2002). “Commitment to Organizational Change: Extension of a ThreeComponent Model" in Journal of Applied Psychology, 87(3), pp.474-487.

Hsu, M.H. et al. (2006). “A Longitudinal Investigation of Continued Online Shopping Behavior: An Extension of the Theory of Planned Behavior" in International Journal of Human Computer Studies, Vol.64, No.9, pp.889-904.

Jones, R.A., N.R. Jimmieson \& A. Griffiths. (2005). "The Impact of Organizational Culture and Reshaping Capabilities on Change Implementation Success: The Mediating Role of Readiness for Change" in Journal of Management Studies, 42, pp.361-386.

Katz, D. \& R.L. Kahn. (1978). The Social Psychology of Organizations. New York: Wiley, $2^{\text {nd }}$ edition.

Kim, S.E. \& J.W. Lee. (2009). "The Impact of Management Capacity on Government Innovation in Korea: An Empirical Study" in International Public Management Journal, 12(3), pp.345-369.

Lee, M.C. (2009). "Understanding the Behavioural Intention to Play Online Games: An Extension of the Theory of Planned Behaviour" in Online Information Review, 33, pp.849-872.

Lewin, Kurt. (1947). “Group Decisions and Social Change" in T.M. Newcomb \& E.L. Hartley [eds]. Readings in Social Psychology. New York: Henry Holt.

Loewenstein, G. et al. (2011). "Risk as Feelings" in Psychological Bulletin, 127(2), pp.267-286.

Lufunyo, Hussein. (2013). "Impact of Public Sector Reforms on Service Delivery in Tanzania" in
IJSST: International Journal of Social Science Tomorrow, Vol.2, No.2 [February]. Available online also at: http://www.tanzania.go.tz/egov uploads/ documents/PSRP_Service delivery_sw.pdf [accessed in Serdang, Malaysia: 7 January 2017].

Madsen, S.R. (2003). "Wellness in the Workplace: Preparing Employees for Change" in Organization Development Journal, 21(1), pp.46-55.

Melitski, J., D. Gavin \& J. Gavin. (2010). "Technology Adoption and Organizational Culture" in International Journal of Organisation Theory and Behaviour, 13(4), pp.546-568.

Mulford, Bill. (2003). "School Leaders: Challenging Roles and Impact on Teacher and School Effectiveness". OECD Commissioned Paper at the Faculty of Education, University of Tasmania. Available online also at: http://www.oecd.org/ edu/school/37133393.pdf [accessed in Serdang, Malaysia: 7 January 2017].

Newton, J. et al. (2003). "Receptivity to Change in a General Medical Practice" in British Journal of Management, 14, pp.143-153.

Oakland, J.S. \& S. Taner. (2007). "Successful Change Management" in Total Quality Management, 18(1/2), pp.1-9.

Pajeres, F. (1996). "Self-Efficacy Beliefs in Academic Settings" in Review of Educational Reserch, 66(4), pp.543-578.

Paton, R.A. \& J. McCalman. (2008). Change Management: A Guide to Effective Implementation. London: Sage Publications Ltd., $3^{\text {rd }}$ edition.

Pollitt, C. \& G. Bouckaert. (2011). Public Management Reform: A Comparative Analysis NPM, Governance and the Neo-Weberian State. Oxford: Oxford University Press.

Prager, Katrin. (2012). "Understanding Behaviour Change: How to Apply Theories of Behaviour Change to SEWeb and Related Public Engagement Activities". Available online at: http://www. environment.scotland.gov.uk [accessed in Serdang, Malaysia: 7 January 2017].

Rinuastuti, H. et al. (2014). "Measuring Hofstede" s Five Cultural Dimensions at Individual Level and its Application to Researchers in Tourists' Behaviors" in International Business Research, 7(12), pp.143-153.

Robinson, R.P. \& D. Doverspike. (2006). “Factors Predicting the Choice of an Online Versus a Traditional Course" in Teaching of Psychology, 33(1), pp.64-68.

Rodsutti, M.C. \& F.W. Swierczek. (2002). "Leadership and Organisational Effcetiveness in Multinational Enterprises in South East Asia" in Leadership and Organisational Development Journal, 23(5), pp.250-259.

Rusly, F.H., J.L. Corner \& P. Sun. (2012). "Positioning 
Change Readiness in Knowledge Management Research" in Journal of Knowledgment Management, 6(2), pp.329-355.

Schein, E.H. (1990). "Innovative Cultures and Adaptive Organisation" in Sri Lanka Journal of Development Administration, 7(2), pp.9-39.

Self, D.R. \& M. Schraeder. (2009). "Enhancing the Success of Organizational Change: Matching Readiness Strategies with Sources of Resistance" in Leadership and Organizational Development Journal, 30(2), pp.167-182.

Shah, H. \& E. Dawnay. (2005). "Behavioural Economics: 7 Principles for Policymakers" in $\mathrm{New}$ Economic Foundation. Available online at: http:// b.3cdn.net/nefoundation/cd98c5923342487571 v8m6b3g15.pdf [accessed in Serdang, Malaysia: 7 January 2017].

Shove, E. (2010). "Beyond the ABC: Climate Change Policy and Theories of Social Change" in Environment \& Planning, 42, pp.1273-1285.

Taylor, D. et al. (2006). A Review of the Use of the Health Belief Model (HBM), the Theory of
Reasoned Action (TRA), the Theory of Planned Behaviour (TPB), and the Trans-Theoretical Model (TTM) to Study and Predict Health Related Behaviour Change. London: NICE Publisher.

Van de Ven, A.H. \& M.S. Poole. (1995). "Explaining Development and Change in Organizations" in Academy of Management Review, 20, pp.510-540. Wallinger, J. (2008). "Toward a Theory of Change Readiness: The Roles of Appraisal, Focus, and Perceived Control" in The Journal of Applied Behavioural Science, 44(3), pp.315-347.

Webb, T.L., F.F. Sniehotta \& F. Michie. (2010). "Using Theories of Behaviour Change to Inform Interventions for Addictive Behaviours" in Addiction, 105, pp.1879-1892.

Weiner, J.B. (2009). "A Theory of Organizational Readiness for Change" in Implementation Science, 67(4), pp.1-9.

Wekman, R.A. (2009). "Understanding Failure to Change: A Pluralistic Approach and Five Patterns" in Leadership \& Organization Development Journal, 30(7), pp.664-684. 
NNAMDI OGBODOAKUM \& NORHASNI ZAINAL ABIDDIN,

Theory of Planned Behaviour and Readiness for Changes

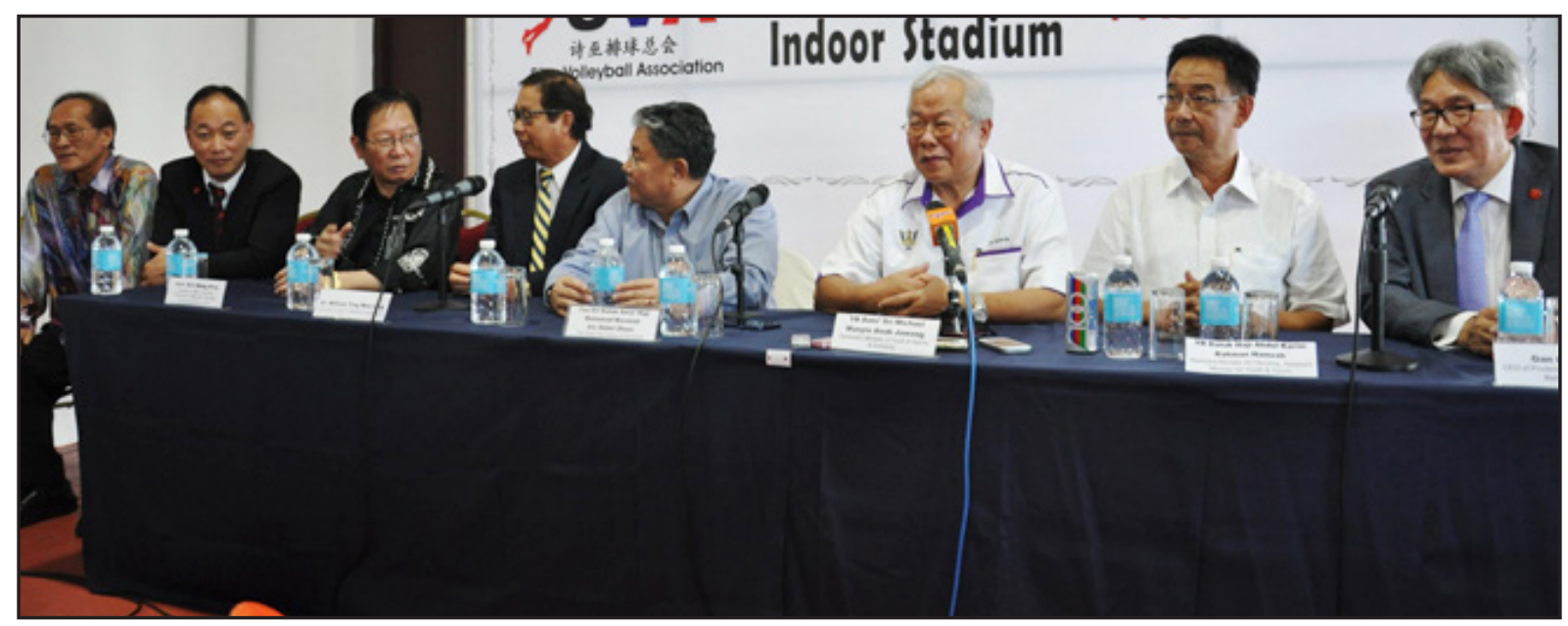

The Private Sector Organisation in Malaysia

(Source: http://www.theborneopost.com, 15/1/2017)

Numerous organisation change improvements have not delivered the target objectives or achieved the intended results, even though significant resources have been allocated. In private sector organisations, such failures have resulted in high management turnover; while in public sector, reorganisations and redeployments of civil servants are on the increase. In the above instances, the common denominator is that for companies, shareholders are responding to competitive pressures occasioned by poor performance to effect the change; while in government agencies and departments, citizenry are demanding proper accountability in service delivery. Although, the private and public organisations have different priorities, policies, and procedures including different cultural environment, they want competent employees, who can deliver improved organisation objectives. 